\title{
THE USE OF VACUUM IMPREGNATION TECHNOLOGY TO IMPROVE SMOKING PROCESS
}

\author{
Rodiah Nurbaya Sari ${ }^{*}$, Diah L. Ayudiarti1), Gunawan ${ }^{3)}$ \\ 1)Center for Research and Development of Product Processing and \\ Biotechnology of Marine and Fisheries \\ 2)Indonesian Research Institute for Fisheries Post-harvest Mechanization \\ *e-mail: rodiah_ns@yahoo.com/rodiah_ns@kkp.go.id
}

\begin{abstract}
One of the new technologies contributing to preserve of the original properties of food (as fruit or vegetables or fish) is vacuum impregnation. Vacuum impregnation is one method to preserve foods using vacuum and pressure to fill the porous with osmotic solution. The application of vacuum impregnation had been conducted on smoked processing using liquid smoke for catfish fillet (Pangasius sp) and tilapia fillet (Oreochomis sp). Vacuum impregnation tool was used having $5 \mathrm{~kg}$ capacity of fillet product, vacuum pressure at $0.71 \mathrm{~kg} / \mathrm{cm}^{2}$ and range of $0-6 \mathrm{~kg} / \mathrm{cm}^{2}$ impregnation pressure. The research had done using osmotic solution with liquid smoke $1.5 \%$ and $17.4 \mathrm{~g}$ of salt/liter of water and the tool was set at condition of 0.71 $\mathrm{kg} / \mathrm{cm}^{2}$ vacuum pressure and variations treatment such of vacuum process time (5 and $10 \mathrm{~min}$ ), impregnation pressure $\left(1\right.$ and $\left.2 \mathrm{~kg} / \mathrm{cm}^{2}\right)$, and impregnation process time $(5,15$, and $25 \mathrm{~min}$ ). Each treatment was done in two replications. Analysis of these fillets before smoking process such of water content, protein content, fat content, color measurement, and hardness (cutting force). After smoking process these fillets are also analyzed for phenols content. Results showed that based on several parameters of the treatment, smoked fillet of catfish needed 35 minutes with phenol content $0.34 \mathrm{mg} / \mathrm{kg}$ and tilapia 25 minutes with $16.40 \mathrm{mg} / \mathrm{kg}$ phenol content. Thus by using vacuum impregnation tool could be shortening the smoking process for both of fillet.
\end{abstract}

Keywords: fillet, liquid smoke, original properties, vacuum impregnation

\section{INTRODUCTION}

Smoking is the oldest known method used for preserving fish. At present, the effects of brining and smoking on colour and sensory perception are at least as important as the preservative effect. There are three different steps of the total smoking process; brining, heating, and smoking (Aminullah et al. 1986). Several studies have been reported on the effect of different smoking processes on fish quality (Cuppet et al. 1989; Espe et al. 2002; Jittinandana et al. 2002).

The modern smoking process is done by using liquid smoke. Liquid smoke has advantages such as easy to apply, smoke concentration can be adjusted according to consumer tastes, the product has a uniform appearance and environmentally friendly (Swastawati, 2011). Furthermore, the important thing is liquid smoke not only instrumental in shaping sensory characteristics but also in terms of food security (Guilén and Cabo 2004; Suñen et al. 2001; de Roos 2003; Darmadii 2006; Bortolomeazzi et al. 2007; Martinez et al. 2011). 
Smoked fish is a traditional food products (exotic indigenous food) are very well known by the people of Indonesia. Various processed products of smoked fish products in Indonesia has become typical of the region, among others, are fish sale (West Sumatra, North Sumatra, and South Kalimantan), pe and iwak grilled fish (Central Java and East Java), fish fufu (North Sulawesi and Gorontalo), wooden fish (Southeast Sulawesi and West Papua) and fish asr (Maluku). Attention to the location of products in the various provinces, then from the other side shows the huge market potential of smoked fish in the country. Even the fish processed had export markets, namely: wood fish (semi-dried skipjack stick) and smoke dried sea cucumbers (dried-smoked sea cucumber) (Sumaryanto et al. 2010).

Common problems being faced by the smoked traditional fish processors are they don't concern for the quality and food safety level also fish processing techniques are still done manually without regard to sanitation and hygiene so the quality is low (Anisah 2007). And generally in Indonesia the curing process is still done in traditional so the process requiresd a longer time.

Technology that can reduce food preservation (fruits, vegetables, and fish) process time (including the smoking) is a technology with a vacuum impregnation technique (VI) and osmotic dehydration (OD) involving hydrodynamic mechanism (HDM). Vacuum impregnation of a porous product consists of exchanging the internal gas or liquid occluded in open pores for an external liquid phase, due to the action of hydrodynamic mechanisms promoted by pressure changes (Fito 1994; Fito and Pastor 1994). The operation is carried out in two steps after the product immersion in the tank containing the liquid phase. In the first step, vacuum pressure ( $p_{1} \sim 50-100$ mbar) is imposed on the system for a short time $\left(t_{1}\right)$ in the close tank, thus promoting the expansion and outflow of the product internal gas. The releasing of the gas take the product pore native liquid with it. In the second step the atmospheric pressure $\left(p_{2}\right)$ is restored in the tank for a time $\left(t_{2}\right)$, and compression leads to a great volume reduction of the remaining gas in the pores and so to the subsequent inflow of the external liquid in the porous structure. Compression can also reduce the pore size depending on the mechanical resistance of the solid matrix (Fito et al. 2001).

This research applying vacuum impregnation technology in smoking catfish and tilapia filet using a vacuum impregnation tool that designed by Research Center for Marine and Fisheries Product Processing and Biotechnology. And the research purposes was using vacuum impregnation technology could improve smoking process in the quality of smoked fish and the process can be more easily, hygienic, and effective also with a short time.

\section{MATERIALS AND METHODS}

\section{Materials}

Preparation. The fresh catfish (Pangasius sp) and tilapia (Oreochomis sp) were manually filleted without skin. The fillet weight of each sample average 160-200 $\mathrm{g}$ and 105-150 g. The fresh fillet were anlyzed of proximate, such as: salt content (SNI method 01-2354.2-2006), fat 
content (SNI method 01-2354.2-2006), and protein content (IKU method A.5.4-0104/Kieldahl); and texture determination (cutting force).

Osmotic Solution. Osmotic solution consisting of salt $17.4 \mathrm{~g} /$ liter $(1.74 \%)$ and $1.5 \%$ liquid smoke (Bugueno et al. 2001).

The other material such as liquid smoke, salt, and chemicals to anlyze of proximate and phenol. The main tool that used in this reasearch was vacuum impregnation tool (Figure 1). The other for anlyze such as Texture Analyser (TA XT Plus) and Spectrofotometer.

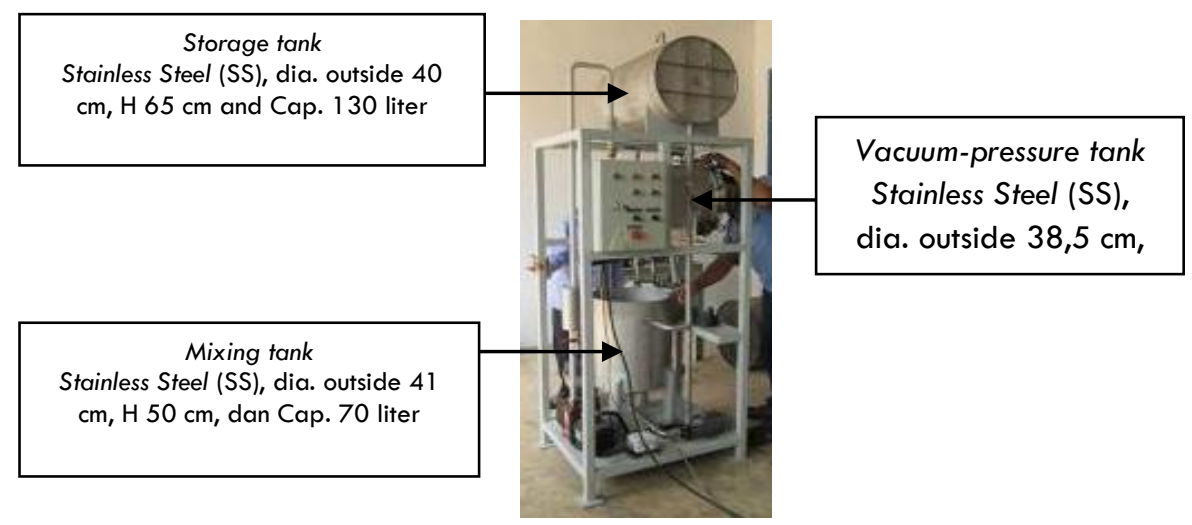

Figure 1. Vacuum impregnation tool (P800 mm X L650 mm X T2390 mm)

\section{Methods}

Vacuum impregnation tool was turned on first. Then preparing the osmotic solution in the mixing tank (mixing tank), mixing them until evenly, and transferred to a storage tank (storage tank). The fillet in vacuum-pressure tank and the vacuum process was begun. Vacuum pressure was set at $0.71 \mathrm{~kg} / \mathrm{cm}^{2}$. Then performed with the variation of pressure impregnation process, 1 and $2 \mathrm{~kg} / \mathrm{cm}^{2}$ (Bugueno et al. 2001). Vacuum impregnation process was carried out at room temperature.

The other treatment variation was during of vacuum process (5 and 10 minutes) (Bugueno et al. 2003; Bugueno et al. 2001) and during of impregnation proces (5, 15, and 25 minutes) (Bugueno ef al. 2001). The replication of experiment was done twice repeats. The smoked fillets were also anlyzed proximate (same as fresh fillets) and phenol content (SMEWW 21 th (2005): 5530-Phenols. B. D).

\section{RESULTS AND DISCUSSION}

Proximate analysis of smoked fillet (salt content, protein content, and fat content). Proximate analysis can be seen in Table 1 whereas the appearance of smoked fillets with vacuum impregnation tool is presented in Figure 2 . 
Table 1. Salt content, protein content, and fat content of smoked fillet

\begin{tabular}{ccccc}
\hline No. & Sample & $\begin{array}{c}\text { Test parameters } \\
\text { Salt Content } \\
(\%)\end{array}$ & $\begin{array}{c}\text { Protein } \\
\text { Content }(\%)\end{array}$ & $\begin{array}{c}\text { Fat Content } \\
(\%)\end{array}$ \\
\hline 1. & FP fresh & $\mathbf{0 , 0 6}$ & $\mathbf{1 5 , 3 3}$ & $\mathbf{8 , 8 8}$ \\
\hline 2. & FPV5T1-5 & 1,55 & 15,82 & 3,26 \\
3. & FPV5T1-15 & 1,49 & 15,87 & 0,15 \\
4. & FPV5T1-25 & 0,58 & 15,46 & 3,26 \\
\hline 5. & FPV10T1-5 & 0,42 & 16,65 & 1,17 \\
6. & FPV10T1-15 & 0,85 & 16,24 & 1,01 \\
7. & FPV10T1-25 & 0,77 & 15,89 & 1,14 \\
\hline 8. & FPV5T2-5 & 0,84 & 16,65 & 0,54 \\
9. & FPV5T2-15 & 1,59 & 16,03 & 1,00 \\
10. & FPV5T2-25 & 0,55 & 15,94 & 1,20 \\
\hline 11. & FPV10T2-5 & 0,69 & 17,00 & 1,39 \\
12. & FPV10T2-15 & 1,04 & 15,38 & 0,85 \\
13. & FPV10T2-25 & 0,76 & 16,04 & 1,01 \\
\hline 14. & FN fresh & $\mathbf{0 , 0 4}$ & $\mathbf{1 7 , 9 4}$ & $\mathbf{0 , 5 5}$ \\
\hline 15. & FNV5T1-5 & 0,70 & 18,56 & 0,58 \\
16. & FNV5T1-15 & 1,45 & 18,98 & 1,44 \\
17. & FNV5T1-25 & 0,71 & 18,09 & 1,26 \\
\hline 18. & FNV10T1-5 & 1,74 & 18,36 & 1,52 \\
19. & FNV10T1-15 & 1,75 & 19,41 & 1,50 \\
20. & FNV10T1-25 & 1,37 & 18,45 & 1,11 \\
\hline 21. & FNV5T2-5 & 0,71 & 18,88 & 0,58 \\
22. & FNV5T2-15 & 1,57 & 18,84 & 1,31 \\
23. & FNV5T2-25 & 1,24 & 18,23 & 1,38 \\
\hline 24. & FNV10T2-5 & 1,17 & 18,37 & 1,45 \\
25. & FNV10T2-15 & 1,58 & 18,27 & 1,49 \\
26. & FNV10T2-25 & 0,71 & 17,88 & 1,02 \\
\hline
\end{tabular}

* Note: FP: catfish fillet, FPV5T1-5: fillet, vacuum process for 5 minutes, impregnation pressure $1 \mathrm{~kg} / \mathrm{cm}^{2}$ during 5 minutes, FN: tilapia fillet, FNV5T 1-5: tilapia fillet, vacuum process for 5 minutes, impregnation pressure $1 \mathrm{~kg} / \mathrm{cm}^{2}$ during 5 minutes

Salt content of these fillets were still below the maximum limit specified by SNI 2725.1: 2009 of $4 \%$ mass fraction (smoked fish) and SNI 2721.1-2009 is $20 \%$ mass fraction (dried salted fish). The using of salt in the smoking process because salt can attract water molecules around it (hydrated ions). The higher of salinity, the more water was withdrawn by the ion hydrate (Desrosier and Muljohardjo 1988).

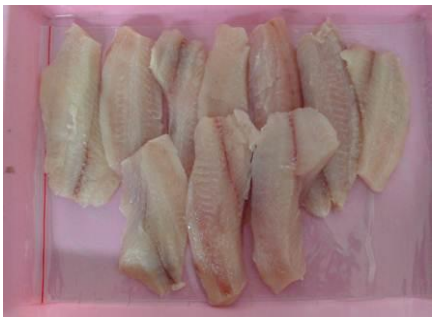

FPV5T1-5

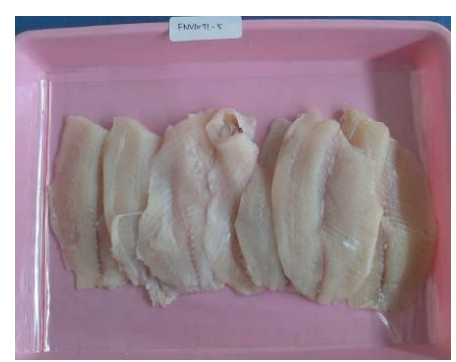

FPV10T1-5

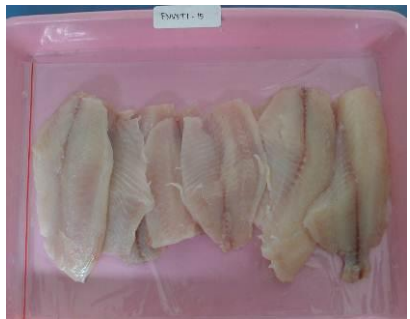

FPV5T1-15

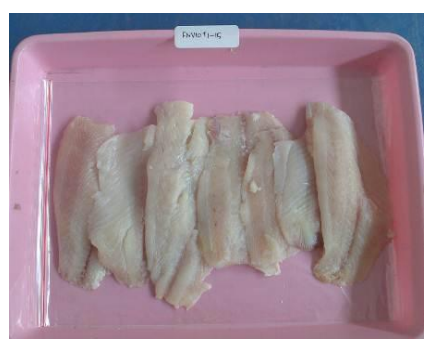

FPV10T1-15

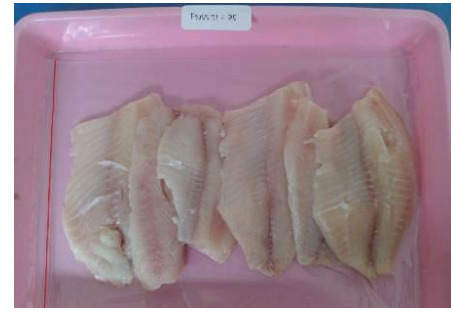

FPV5T1-25

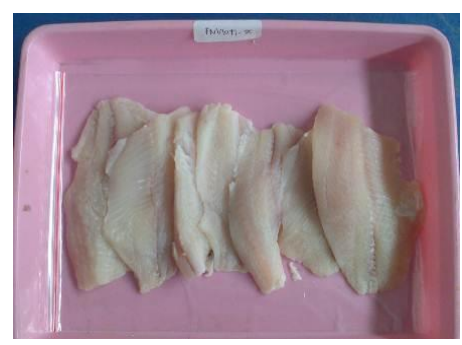

FPV10T1-25 


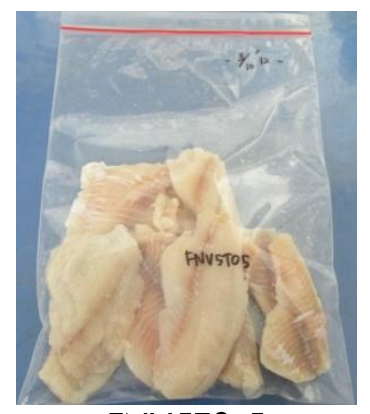

FNV5T0-5

Figure 2. The appearance smoked fillets with vacuum impregnation tool

Hardness (Cutting force). Result of smoked fillet of cutting force can be seen in Table 2.

Almost all treatments had a higher cutting force values than the fresh filet conditions. Barat et al. (1999) conducted that the sample had progressive relaxation volume after compression-induced time pressure impregnation maintained. Changes in sample volume would show the effect of suction on the external solution in accordance with the pressure gradient and hydrodynamic flow paired with salt diffusional capture.

\begin{tabular}{|c|c|c|}
\hline No. & Sample & $\begin{array}{l}\text { Cutting force } \\
\left(\mathrm{gf} / \mathrm{cm}^{2}\right)\end{array}$ \\
\hline 1. & FP fresh & 3878,35 \\
\hline 2. & FPV5T1-5 & 9038,08 \\
\hline 3. & FPV5T1-15 & 10164,51 \\
\hline 4. & FPV5T1-25 & 3688,53 \\
\hline 5. & FPV10T1-5 & 13632,60 \\
\hline 6. & FPV10T1-15 & 13913,34 \\
\hline 7. & FPV10T1-25 & 7291,75 \\
\hline 8. & FPV5T2-5 & 1635,79 \\
\hline 9. & FPV5T2-15 & 2476,34 \\
\hline 10. & FPV5T2-25 & 6634,37 \\
\hline 11. & FPV10T2-5 & 7997,62 \\
\hline 12. & FPV10T2-15 & 6634,59 \\
\hline 13. & FPV10T2-25 & 10556,55 \\
\hline 14. & FN fresh & 2144,19 \\
\hline 15. & FNV5T1-5 & 2512,00 \\
\hline 16. & FNV5T1-15 & 2852,63 \\
\hline 17. & FNV5T1-25 & 3818,57 \\
\hline 18. & FNV10T1-5 & 4696,49 \\
\hline 19. & FNV10T1-15 & 3874,88 \\
\hline 20. & FNV10T1-25 & 4223,23 \\
\hline 21. & FNV5T2-5 & 2422,72 \\
\hline 22. & FNV5T2-15 & 1843,60 \\
\hline 23. & FNV5T2-25 & 3299,49 \\
\hline 24. & FNV10T2-5 & 5052,59 \\
\hline 25. & FNV10T2-15 & 3897,11 \\
\hline 26. & FNV10T2-25 & 4266,32 \\
\hline
\end{tabular}

* Note: FP: catfish fillet, FPV 5T1-5: fillet, vacuum process for 5 minutes, impregnation pressure $1 \mathrm{~kg} / \mathrm{cm}^{2}$ during 5 minutes, FN: tilapia fillet, FNV5T 1-5: tilapia fillet, vacuum process for 5 minutes, impregnation pressure $1 \mathrm{~kg} / \mathrm{cm}^{2}$ during 5 minutes

Phenol Content. Result of smoked fillet of phenol content could be seen at Table 4 below.

The resulting phenol content lower than resulted of Rama et al. (2013) which stated phenol for catfish filet smoke using liquid smoke with $7 \%$ concentration for 60 minutes was $10.63 \mathrm{mg} / \mathrm{kg}$. This case was assumed due to the relative availability of water on fat content and the smoking process affected the solubility diffusion and preventing water interstitial and 
fatty compounds from taking smoke component also influenced by the thickness of the filet (Clifford 1980).

Tabel 4. Phenol content of smoked fillet

\begin{tabular}{|c|c|c|}
\hline No. & Sample & $\begin{array}{c}\text { Phenol Content } \\
(\mathrm{mg} / \mathrm{kg})\end{array}$ \\
\hline 1. & FP fresh & $e^{2}$ \\
\hline 2. & FPV5T1-5 & 0,01 \\
\hline 3. & FPV5T1-15 & 0,01 \\
\hline 4. & FPV5T1-25 & 0,01 \\
\hline 5. & FPV10T1-5 & 0,23 \\
\hline 6. & FPV10T1-15 & 0,01 \\
\hline 7. & FPV10T1-25 & 0,01 \\
\hline 8. & FPV5T2-5 & 0,04 \\
\hline 9. & FPV5T2-15 & 0,27 \\
\hline 10. & FPV5T2-25 & 0,23 \\
\hline 11. & FPV10T2-5 & 0,14 \\
\hline 12. & FPV10T2-15 & 0,34 \\
\hline 13. & FPV10T2-25 & 0,28 \\
\hline 14. & FN segar & - \\
\hline 15. & FNV5T1-5 & 17,30 \\
\hline 16. & FNV5T1-15 & 11,97 \\
\hline 17. & FNV5T1-25 & 15,11 \\
\hline 18. & FNV10T1-5 & 7,76 \\
\hline 19. & FNV10T1-15 & 16,40 \\
\hline 20. & FNV10T1-25 & 17,35 \\
\hline 21. & FNV5T2-5 & 16,91 \\
\hline 22. & FNV5T2-15 & 15,55 \\
\hline 23. & FNV5T2-25 & 10,53 \\
\hline 24. & FNV10T2-5 & 11,60 \\
\hline 25. & FNV10T2-15 & 17,11 \\
\hline 26. & FNV $10 T 2-25$ & 14,73 \\
\hline
\end{tabular}

* Note: FP: catfish fillet, FPV5T1-5: fillet, vacuum process for 5 minutes, impregnation pressure $1 \mathrm{~kg} / \mathrm{cm}^{2}$ during 5 minutes, $\mathrm{FN}$ : tilapia fillet

\section{CONCLUSIONS}

The best treatment that produced the best smoked fillet based on these analysis parameters for catfish was vacuum processed for 10 minutes and impregnated with $2 \mathrm{Kg} / \mathrm{cm}^{2}$ pressure for 25 minutes while for tilapia was vacuum processed for 10 minutes and impregnated with $1 \mathrm{Kg} / \mathrm{cm}^{2}$ pressure for 15 minutes.

The use of vacuum impregnation on the fillet smoking process with liquid smoke could accelerate the time, for catfish was 35 minutes (time total) with phenol content reached a maximum of $0.34 \mathrm{mg} / \mathrm{kg}$ and tilapia was 25 minutes with phenol content reached a maximum of $16.40 \mathrm{mg} / \mathrm{kg}$.

\section{REFERENCES}

Aminullah BAKM, Ratnayake WMN, Ackman RG. 1986. Effect of Smoking on The Proximate Composition of Atlantic Mackerel (Scomber scombrus). Journal of Food Science. 51(2): 327-329.

Anisah RN. 2007. Analisis Tingkat Keberdayaan Pengolah lkan yang Berorientasi Pasar (Studi Empiris di Kota Tegal). Tesis. Program Pascasarjana. Semarang: Universitas Diponegoro.

Barat JM, Albros A, Chiralt A, Fito P. 1999. Equilibration of Apple Tissue in Osmotic Dehydration: Microstructural Changes. Drying Technology. 17 (7 \& 8): 1375-1386.

[BSN] Badan Standarisasi Nasional. 2006. Test Methods of Chemistry - Part 2: The Determination of Water Content in Fishery Products. Jakarta: SNI 01-2354.2-2006.

[BSN] Badan Standarisasi Nasional. 2009. Ikan Asin Kering.-Bagian 1: Spesifikasi. Jakarta: SNI 2721.1: 2009. 
[BSN] Badan Standarisasi Nasional. 2009. Ikan Asap-Bagian 1: Spesifikasi. Jakarta: SNI 2725.1:2009.

Bugueno G, Escriche I, Chiralt A, Perez-Juan M, Serra JA, Camacho MM. 2001. Use of Vacuum Impregnation in Smoked Salmon Manufacturing. Osmotic Dehydration \& Vacuum Impregnation. Application in Food Industries. Chapter 17: 195-206. Basel: Technomic Publishing Co., Inc. Lancaster.

Bugueno G, Escriche I, Martinez-Navarrete N, Camacho MDM, Chiralt A. 2003. Influence of Storage Condition on some Physical and Chemical Properties of Smoked Salmon (Salmo salar) Processed by Vacuum Impregnation Techniques. Food Chemistry. 81: 85-90.

Bortolomeazzi R, Sebastianutto N, Toniolo R, Pizzariello A. 2007. Comparative Evaluation of the Antioxidant Capacity of Smoke Flavouring Phenol by Crocin Bleaching Inhibition, DPPH Radical Scavenging and Oxidation Potential. Food Chemistry Journal. 100 (4): $1481-1489$.

Clifford MN. 1980. Smoking of Food. Process Biochemistry. 15: 8-1 1.

Cuppet SL, Gray JI, Booren AM, Price JF, Stachiw MA. 1989). Effect of Processing Variables on Lipid Stability in Smoked Great Lakes Whitefish. Journal of Food Science. 54(1): 52-54.

Darmadji P. 2006. Produksi Biopreservatif Asap Cair Cangkang Sawit dan Aplikasinya untuk Bidang Pangan, Hasil Perkebunan dan Kehutanan. Laporan Seminar Penggunaan Bahan Alami untuk Pengawetan Ikan. Jakarta: Balai Besar Riset dan Pengolahan Produk dan Bioteknologi Kelautan dan Perikanan dan ISPIKANI.

de Roos KB. 2003. Effect of Texture and Microstructure on Flavour Retention and Release. International Dairy Journal. 13 (8): 593-605.

Desrosier NW, Muljohardjo M. 1988. Teknologi Pengawetan Pangan, Jakarta: Universitas Indonesia. 624 pp.

Espe M, Nortvedt R, Lie Q, Hafsteinsson H. 2002. Atlantic Salmon (Salmo salar, L.) as Raw Material for The Smoking Industry. II: Effect of Different Smoking Methods on Losses of Nutrients and on The Oxidation of Lipids. Food Chemistry. 77: 41-46.

Fito P. 1994. Modelling of Vacuum Osmotic Dehydration of Food. Journal of Food Enginering. 22: 313-328.

Fito P, Pastor R. 1994. On some non-Diffusional Mechanism occurring during Vacuum Osmotic Dehydration. Journal of Food Engineering. 21: 513-510.

Fito P, Chiralt A, Barat JM, Andres A, Monzo JM, Navarrete NM. 2001. Vacuum Impregnation for Development of New Dehydrated Products. Journal of Food Engineering. 49: 297 302.

Guillen MD, Cabo N. 2004. Study of The Effects of Smoke Flavourings on The Oxidative Stability of The Lipids of Pork Adipose Tissue by Means of Fourier Transform Infrared Spectroscopy. Spain: Meat Science.

llyas S. 1972. Pengantar Pengolahan Ikan. Jakarta: Lembaga Penelitian Teknologi Perikanan.

Jittinandana S, Kenney PB, Slider SD, Kiser RA. 2002. Effect of Brine Concentration and Brine Time on Quality of Smoked Rainbow Trout Fllets. Journal of Food Science. 67: 20952099.

Martinez O, Salmerón J, Guillén MD, Casas, C. 2011. Characteristic of Dry and Brine Salted Salmon later Treated with Liquid Smoke Flavourings. Agricultural and Food Science. 20: 217-227.

Rama F, Sari NI, Loekman S. 2013. Effect of Different Liquid Smoke Use Consumer Acceptance Catfish (Pangasius hypopthalmus) Smoke. http://repository.unri.ac.id/bitstream/1 23456789/1516/1/Fajri\%20Rama\%20\%200604113617.pdf. Diakses pada tanggal 19 September 2013.

[SMEWW] Standard Methods for the Examination of Water and Wastewater. 2005. 21 th Edition: 5530.

Sumaryanto H, Santoso J, Muhandri, T. 2010. Pengembangan Teknologi Pengasapan Ikan yang Efisien Menggunakan Bahan Baku Lokal dan Berorientasi Pasar dengan UKM sebagai Sentra Pengembangan. Institut Pertanian Bogor Lembaga Penelitian dan Pengabdian Kepada Masyarakat

Suñen E, Fernandez-Galian B, Aristimuño, C. 2001. Antibacterial Activity of Smoke Wood Condensates againts Aeromonas hydrophila, Yersinia enterocolitica and Listeria monocytogenes at Low Temperature. Food Microbiology. 18 (4): 387-393. 
Swastawati F. 2011 . Studi Kelayakan dan Efisiensi Usaha Pengasapan Ikan dengan Asap Cair Limbah Pertanian. Fakultas Perikanan dan Ilmu Kelautan. Semarang: Universitas Diponegoro.

Winarno FG. 1995. Enzim Pangan. Gramedia Pustaka Utama, Jakarta. $115 \mathrm{hlm}$. 